\title{
Adversity Quotient (AQ) dan Stres Kerja Pegawai Bagian Protokol Pemerintah Provinsi Jambi
}

\author{
Imam Kurniawan dan Ema Krisnawati \\ Universitas Jambi
}

\begin{abstract}
A precedence employee works not only in the office but also in the field. Fieldwork sometimes makes scheduled jobs changed at any time. This happens when a government leader visits the office. In that case, the precedence officer is obliged to facilitate all the attending guests to the event. This condition requires precedence employees to be available 24 hours a day. The number of jobs that must be completed in a short time can cause work stress on precedence employees. There are several ways to reduce work stress, such as having reasonable confidence, high work motivation, and adversity quotient. The ability of Adversity Quotient $(A Q)$ is an individual's ability to face adversity and turn it into a challenge. The data retrieval techniques employed used the adversity quotient scale from Stoltz theory (2003) and work stress scale from Robbins theory (1996). The analysis technique in this research used by Pearson productmoment. The results of this study showed a significant correlation between adversity quotient and job stress $(r=-0.426, p=0.019)$. This study shows the level of work stress will be reduced if the precedence employees have a high Adversity quotient.
\end{abstract}

Keywords: Adversity Quotient; Job Stress; Precedence.

Pegawai protokol tidak hanya bekerja di kantor tetapi juga di lapangan. Situasi kerja di lapangan terkadang membuat jadwal yang sudah dijadwalkan dapat berubah sewaktu-waktu. Pejabat yang melakukan blusukan, memfasilitasi seluruh tamu pemerintah yang datang, dan harus siap sedia 24 jam ketika dibutuhkan. Hal ini dapat menyebabkan stres kerja pada pegawai tersebut. Ada beberapa cara untuk menurunkan stres kerja antara lain kepercayaan diri, motivasi dan adversity quotient. Kemampuan Adversity Quotient (AQ) merupakan kemampuan individu yang dapat menghadapi kesulitan dan mengubahnya menjadi tantangan. Teknik pengambilan data menggunakan skala adversity quotient dari teori Stoltz (2003) dan skala stres kerja dari teori Robbins (1996). Teknik analisis pada penelitian ini menggunakan pearson product moment. Ada hubungan negatif antara adversity quotient dengan stres kerja pegawai bagian protokol Pemerintah Provinsi Jambi $(r=-0.426, p=0.019)$. Penelitian ini menunjukkan semakin tinggi adversity quotient pegawai bagian protokol maka semakin rendah pula stres kerja pegawai bagian protokol Pemerintah Provinsi Jambi.

Kata kunci: Adversity Quotient (AQ); Stres Kerja; Protokol. 
Pemerintah Provinsi Jambi terbagi menjadi instansi-instansi yang bergerak sesuai pada nama instansi tersebut dan mempunyai job desk masing-masing. Tetapi protokol mempunyai tugas yang berbeda dengan dinas lainnya. Berdasarkan data yang didapat dari pengambilan data awal yang dilakukan oleh peneliti melalui wawancara pada P seorang protokol pada tanggal 26 Februari 2018, peneliti melihat perbedaan di bagian protokol yang berbeda dari dinas lainnya. Bagian protokol mempunyai tugas dalam mengatur penerimaan tamu, pelayanan dan akomodasi tamu, memberikan pengendalian fasilitas pada penerimaan tamu, memandu tamu selama berada di daerah, menata tempat yang akan dihadiri tamu dan pejabat, mengantar dan menjemput serta mengurus surat-surat ijin keluar negeri para pejabat, perjalanan dinas pimpinan dan pejabat daerah, menyusun susunan acara upacara, membawa acara, menerima, mengatur, mengendalikan, mengumpulkan bahan dan data rapat, serta mengecek, mengendalikan, memantau peralatan kantor yang digunakan.

Setiap acara pemerintahan kita melihat selalu berjalan dengan lancar dan ditata dengan sebaik-baiknya. Baik itu acara Presiden, Gubernur, maupun setingkat Walikota/Bupati. Dalam acara tersebut pemerintahan mempunyai kesekretariat untuk mengatur pelaksanaan acara resmi dari pemerintahan. Berdasarkan UU No. 9 Tahun 2010 setiap tingkatan pemerintahan negara mempunyai bagian protokol untuk mengatur protokoler kepala pemerintahan Negara, Provinsi, dan Kabupaten/Kota.

Pemerintah Provinsi Jambi, protokoler diatur dalam Perda Provinsi Jambi No. 3 Tahun 2015. Protokoler adalah serangkaian aturan dalam acara kenegaraan atau acara resmi yang meliputi aturan mengenai tata tempat, tata upacara dan tata penghormatan sehubungan dengan penghormatan kepada seseorang sesuai dengan jabatan dan/atau kedudukannya dalam negara, pemerintahan atau masyarakat. Sehingga, pada struktur Sekretariatan Daerah Jambi ada bagian biro humas dan protokol yang terdiri dari bagian pemberitaan dan publikasi, pelayanan media dan dokumentasi, dan protokol. Individu yang menjalankan tugas protokoler bekerja dibagian protokol.

Menurut Nasution (Hernani, 2014) protokol merupakan aturan baku yang menyangkut penyelanggaraan acara-acara resmi (pemerintah) atau cara dalam memberlakukan pejabat pemerintah aktivitas kedinasan dan cara diselenggarakan oleh instansi pemerintah atau 
masyarakat umum, sehingga pegawai yang bekerja dalam lingkup protokol harus dapat menerapkan protokol pada setiap kegiatan pemerintahan.

Pegawai bagian protokol (R, 22 Januari 2018) menjelaskan, bahwa tugasnya harus mengatur acara yang akan dihadiri oleh pejabat daerah. Mulai dari kegiatan pejabat yang harus dihadiri atau cara yang harus dilakukan pejabat dalam suatu kegiatan. Selain itu, ia juga mengatakan beberapa kendala yang sering ia alami saat bertugas. Seperti pejabat memiliki jadwal yang sangat padat dan banyak, itu membuat ia harus mengatur acara tersebut agar tepat waktu. Selain itu ketika malam hari baru pulang dinas dari luar kota, namun paginya sudah harus sedia mengikuti jadwal pejabat yang sudah ditentukan oleh bagian protokol.

Peneliti juga melakukan wawancara kepada pegawai bagian protokol Pemerintah Provinsi Jambi (E, 1 Maret 2018). Ia menjelaskan kesulitan dalam berkonsentrasi karena takut akan adanya kesalahan saat acara berjalan. Kemudian ia juga mengatakan selalu bertanya kesiapan kepada petugas-petugas yang bertugas pada saat acara tersebut terkhususnya pada saat acara-acara besar Pemerintah Provinsi Jambi seperti Hari Ulang Tahun (HUT) Provinsi Jambi, kunjungan kerja dari menteri dan atau pemerintah pusat, Hari Ulang Tahun (HUT) Republik Indonesia, dan acara-acara lain yang mengundang peserta sekala Nasional maupun Internasional. Ia juga mengungkapkan, bahwa ia pernah merasakan pusing saat adanya perdebatan karena ketidak sepahamannya antara lembaga adat dan panitia penyelenggara yang menyebabkan perdebatan yang cukup lama serta memakan waktu yang lama pula. Serta ia juga menceritakan sering merasa susah berkonsentrasi disaat rangkaian acara yang pada suatu kegiatan tertentu lumayan panjang.

Situasi tersebut berpengaruh terhadap kinerja pegawai bagian protokol Pemerintah Provinsi Jambi dalam memberikan pelayanan kepada masyarakat. Protokol E juga mengatakan hal tersebut juga akan berdampak kepada kinerja pemerintahan dan pegawai bagian protokol itu sendiri, seperti pegawai merasa motivasi menurun, kemalasan, kemangkiran, kelelahan dan stres kerja.

Salah satu dampak dari kinerja pegawai bagian protokol di atas adalah stres kerja. Robbins dan Judge (Putra, 2015) memberikan definisi stres kerja sebagai suatu kondisi dinamis dimana sesorang individu dihadapkan pada peluang, tuntutan, atau sumber daya yang terkait 
dengan apa yang dihasratkan oleh individu itu dan hasilnya dipandang tidak pasti dan penting. Mangkunegara (Rumimpunu, 2015) mendefinisikan stres kerja sebagai perasaan tertekan yang dialami pegawai dalam menghadapi pekerjaan. Pekerjaan yang banyak dan harus dituntut bekerja harus sesuai dengan yang diharapkan merupakan salah satu faktor membuat karyawan menjadi stres dalam bekerja. Bagian protokol yang mengalami stres kerja sangat berbahaya untuk kesuksesan acara yang sedang ia tangani. Misalnya protokol dalam keadaan stres kerja ia akan merasa gugup dan lupa hal yang harus dilakukan pejabat tersebut atau juga bisa salah dalam tahapan rangkaian acara. Dan itu semua dapat membuat kacau acara yang sudah disusun dengan baik.

Setiap pekerjaan mempunyai indikasi seseorang mengalami stres kerja. Munandar (Haryanti, 2013) mengatakan reaksi-reaksi psikologis, fisiologis, dan atau perilaku terhadap stres adalah hasil interasi situasi dengan individunya, mencakup ciri-ciri kepribadian yang khusus dan pola-pola perilaku yang didasarkan pada sikap, kebutuhan, nilai-nilai, pengalaman masa lalu, keadaan kehidupan dan kecakapan. Kecakapan yang dimaksud antara lain intelegensi, pendidikan, pelatihan, dan pembelajaran. Setiap orang dapat mengolah kecakapan tersebut dan menggunakannya kapanpun dan dimanapun. Dan hal ini lah yang akan membantu seseorang dalam menghadapi kesulitan hidupnya khususnya kesulitan dalam bekerja.

Seseorang tidak akan merasakan dampak dari stres apabila dapat mengatasi kesulitan dalam hidupnya dengan baik. Menurut Anoraga (Rumimpunu, 2015) orang tidak akan mengalami stres apabila dapat beradaptasi dan berjuang antara kebutuhan pekerjaan dengan keinginan-keinginan serta kemampuannya dalam bekerja. Daya juang dan kontrol atau dapat menghadapi pekerjaannya termasuk dalam dimensi Adverity Quotient (AQ). Setiap orang memiliki kemampuan dalam menghadapi kesulitan yang sedang dihadapinya. Ini sejalan dengan Stoltz dan Weihenmayer (Rosita, 2015) situasi sulit dan tantangan dalam hidup dapat diatasi dengan adversity quotient (AQ) yang baik.

Stoltz (2003) menyatakan bahwa $A Q$ merupakan kemampuan seseorang untuk mampu bertahan menghadapi kesulitan dan mampu menghadapi kesulitan tersebut, serta mampu melampaui harapan-harapan atas kinerja dan potensinya. $A Q$ berperan dalam meramalkan dan 
menentukan kesuksesan seseorang. Selanjutnya, Stoltz juga menyatakan bahwa $A Q$ dapat meramalkan kinerja.

Nyoman (Rosita, 2015) orang yang memiliki $A Q$ tinggi tidak akan pernah takut dalam menghadapi berbagai tantangan dalam proses pendakiannya. Bahkan dia akan mampu untuk mengubah tantangan yang dihadapinya dan menjadikannya sebuah peluang. Dengan kata lain AQ dapat membantu seseorang agar tidak stres dalam bekerja. Sehingga pegawai protokol dapat terhindar dari stres kerja dan mengoptimalkan adversity quotient pada dirinya.

\section{Metode}

Penelitian ini dilakukan menggunakan desain penelitian kuantitatif dengan jenis penelitian berdasarkan tujuannya yaitu korelasional. Berdasarkan waktu jenis Penelitian ini adalah analitik cross-sectional, dan berdasarkan perlakuan yang diberikan penelitian ini termasuk jenis penelitian survei. Pelaksanaan penelitian ini dilakukan pada bulan Mei tahun 2018 dan bertempat di Bagian Protokol Biro Humas dan Protokol SETDA Provinsi Jambi. Populasi dan sampel pada penelitian ini adalah seluruh pegawai bagian protokol yang berjumlah 30 orang, dengan teknik pengambilan sampel yaitu total sampling. Instrumen penelitian yang digunakan berupa skala skala adversity quotient dan skala stres kerja.

Skala adversity quotient disusun berdasarkan dimensi-dimensi adversity quotient dari Stoltz (2003). Validitas isi dari penelitian ini menggunakan Profesional Judgment. Reliabilitas skala adversity quotient menghasilkan nilai Crochbach Alpha sebesar 0,828. Sementara itu, skala stre kerja disusun berdasarkan dimensi-dimensi stres kerja menurut Robbins (1996). Validitas isi dari penelitian ini menggunakan Profesional Judgment. Reliabilitas skala stres kerja menghasilkan nilai Crochbach Alpha sebesar 0,953.

Teknik analisis data yang digunakan pada penelitian ini adalah Pearson Product Moment untuk mengetahui hubungan antar variabel dan statistika deskriptif untuk mengetahui gambaran kedua variabel pada subjek serta karakteristik subjek penelitian. 


\section{H a s i 1}

\section{Deskripsi Subjek Penelitian}

Terdapat beberapa karakteristik yang dapat dijelaskan untuk mengetahui gambaran subjek dapat dilihat pada tabel berikut :

\section{Tabel 1}

Karakteristik Responden Berdasarkan Jenis Kelamin

\begin{tabular}{cccc}
\hline No. & Jenis Kelamin & Jumlah & Persentase \\
\hline 1. & Laki-laki & 21 & $70 \%$ \\
2. & Perempuan & 9 & $30 \%$ \\
& Jumlah & 30 & $100 \%$ \\
\hline
\end{tabular}

Pada tabel 1 diketahui bahwa dari total 30 responden penyebaran berdasarkan jenis kelamin yang paling banyak adalah laki-laki sebanyak 21 orang dengan persentase $70 \%$.

Tabel 2

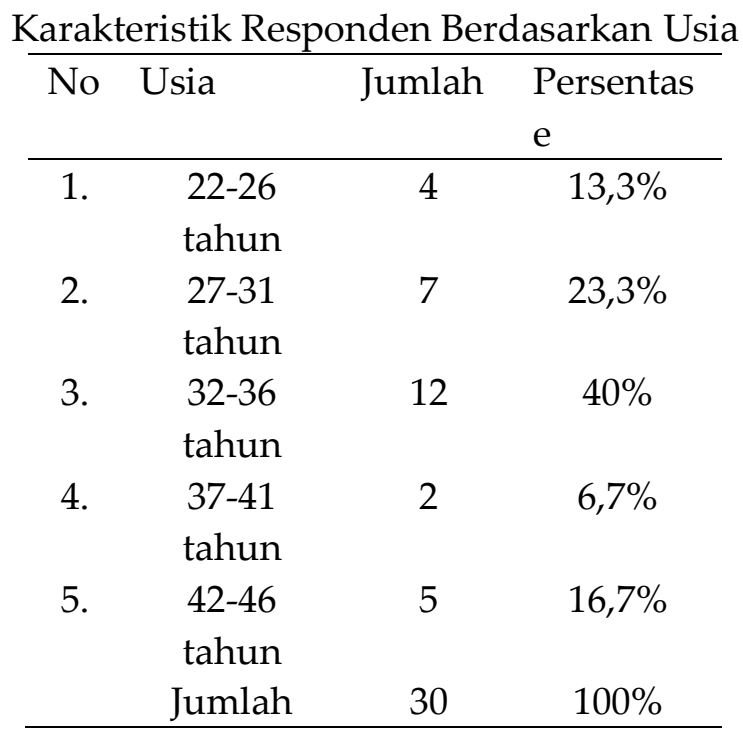

Pada tabel 2 diketahui bahwa dari total 30 subjek penyebaran berdasarkan usia yang paling banyak pada usia 32-36 tahun sebanyak 12 orang dengan persentase $40 \%$. 
Tabel 3

Karakteristik Responden Berdasarkan Masa Kerja

\begin{tabular}{cccc}
\hline No. & Masa Kerja & Jumlah & Persentase \\
\hline 1. & $1-5$ tahun & 10 & $33,3 \%$ \\
2. & $6-10$ tahun & 10 & $33,3 \%$ \\
3. & $11-15$ tahun & 6 & $20 \%$ \\
4. & $16-20$ tahun & - & $0 \%$ \\
5. & $21-25$ tahun & 4 & $13,4 \%$ \\
& Jumlah & 30 & $100 \%$ \\
\hline
\end{tabular}

Pada tabel 3 diketahui bahwa dari total 30 subjek, yang paling banyak adalah pada masa kerja 1-5 tahun dan 6-10 tahun sebanyak 10 subjek (33,3\%)

\section{Hasil Deskriptif Variabel Stres Kerja}

Gambaran stres kerja pada pegawai bagian protokol Pemerintah Provinsi Jambi dapat dilihat pada tabel berikut ini:

Tabel 4

\begin{tabular}{cccc}
\multicolumn{4}{c}{ Kategorisasi Stres Kerja } \\
\hline Variabel & Frekuensi & Persentase & Kategori \\
\hline \multirow{2}{*}{ Stres } & 4 & $13,3 \%$ & Tinggi \\
Kerja & 1 & $3,3 \%$ & Sedang \\
& 25 & $83,4 \%$ & Rendah \\
\hline
\end{tabular}

Pada tabel 4 diketahui bahwa dari total 30 responden, kategorisasi tinggi terdapat 4 subjek (13,3\%), kategorisasi sedang terdapat 1 subjek (3,3\%), dan kategorisasi rendah terdapat 25 subjek $(83,3 \%)$.

Tabel 5

\begin{tabular}{cc}
\multicolumn{2}{c}{ Kontribusi Aspek Stres Kerja } \\
\hline Aspek & Nilai \\
\hline Fisiologis & 0.917 \\
\hline Psikologis & 0.958 \\
\hline Perilaku & 0.937 \\
\hline
\end{tabular}

Berdasarkan tabel 5, kontribusi dari variabel stres kerja jika ditinjau dari setiap aspek terlihat aspek fisiologis mempunyai nilai 0.917, psikologis mempunyai nilai 0.958, dan aspek perilaku mempunyai nilai 0.937 . 


\section{Hasil Deskriptif Variabel Adversity Quotient}

Gambaran adversity quotient pada pegawai Protokol Pemerintah Provinsi Jambi dapat dilihat pada tabel berikut ini:

Tabel 6

Kategorisasi Variabel Adversity Quotient

\begin{tabular}{ccc}
\hline Kategori & Frekuensi & Persentase \\
\hline Tinggi & 26 & $86,7 \%$ \\
\hline Sedang & 3 & $10 \%$ \\
\hline Rendah & 1 & $3,3 \%$ \\
\hline
\end{tabular}

Berdasarkan tabel 26 pada kategorisasi tinggi terdapat 26 subjek (86,7\%), kategorisasi sedang terdapat 3 subjek (10\%), dan kategorisasi rendah terdapat 1 subjek (3.3\%).

Tabel 7

Kontribusi Aspek Variabel Adversity Quotient

\begin{tabular}{cc}
\hline Aspek & Nilai \\
\hline Control & 0.691 \\
\hline Origin & 0.678 \\
\hline Ownership & 0.852 \\
\hline Reach & 0.875 \\
\hline Endurance & 0.816 \\
\hline
\end{tabular}

Berdasarkan dari tabel di atas dapat dilihat pada variabel adversity quotient, aspek control mendapatkan nilai 0.691, sedangkan origin 0.678, sedangkan aspek ownership mempunyai nilai 0.852, kemudian aspek reach mempunyai nilai 0.875 , dan aspek endurance memiliki nilai 0.816 .

\section{Uji Asumsi Analisis Data}

Uji Normalitas

Uji Normalitas dilakukan dengan tujuan untuk mengetahui distribusi data dalam penelitian ini normal atau tidak. Data dinyatakan normal apabila nilai taraf signifikansi (p) hasil One-Sample Kolmogorov-Smirnov Test lebih besar dari 0,05. Hasil uji normalitas pada skala adversity quotient dan skala stres kerja dapat dilihat pada tabel berikut: 
Tabel 8

Hasil Uji Normalitas

\begin{tabular}{ccccc}
\hline No. & Variabel & Nilai & P & Status \\
& & K-S-Z & & \\
\hline 1. & Adversity & 0.676 & $\mathrm{p}>0.05$ & Normal \\
Quotient & & & \\
terhadap Stres & & & \\
Kerja & & & \\
\hline
\end{tabular}

Berdasarkan tabel 8 dapat dilihat bahwa distribusi data dalam skala adversity quotient dan stress kerja yang didistribusikan pada 30 subjek penelitian ialah normal.

Uji Linearitas

Tabel 9

Hasil Uji Linearitas

\begin{tabular}{ccccc}
\hline Variabel & Sig & Nilai & $\mathrm{P}$ & Status \\
\hline Adversity & Linearity & 0,004 & $\mathrm{p}<$ & \\
quotient & & 0,05 & \\
\cline { 2 - 4 } terhadap & Deviation & & $\mathrm{p}>$ & Linear \\
stres & from & 0,048 & 0,05 & \\
kerja & linearity & & & \\
\hline
\end{tabular}

Berdasarkan uji liniearitas di atas, hubungan antara adversity quotient dengan stres kerja menunjukkan Sig.linearity sebesar 0.004 dengan $\mathrm{p}<0.05$ dan Sig.deviation from linearity sebesar 0.048 dengan $\mathrm{p}>0.05$. Oleh karena itu hasil uji linieritas tersebut menunjukkan terdapat hubungan yang linier antara adversity quotient dengan stres kerja, sehingga uji korelasi Pearson dapat dilakukan.

\section{Uji Hipotesis Penelitian}

Berdasarkan hasil uji asumsi yang telah dilakukan, terbukti bahwa variabel adversity quotient dengan stress kerja telah memenuhi uji normalitas dan linearitas. Maka untuk selanjutnya dilakukan analisis data untuk menguji hipotesis, yaitu apakah ada hubungan signifikan antara adversity quotient dengan stres kerja pegawai bagian protokol Pemerintah Provinsi Jambi. Uji hipotesis ini menggunakan korelasi product moment Pearson. 
Tabel 10

Hasil Uji Hipotesis

\begin{tabular}{cccc}
\hline Variabel & $\begin{array}{c}\text { Koefisien } \\
\text { Korelasi } \\
(\mathrm{r})\end{array}$ & $\mathrm{P}$ & Keterangan \\
\hline Adversity & & & \\
quotient & & 0,019 & \\
dengan & $-0,426$ & $<$ & Signifikan \\
stres & & 0,05 & \\
kerja & & & \\
\hline
\end{tabular}

Analisis korelasi menunjukkan bahwa korelasi variabel adversity quotient dengan stres kerja sebesar $\mathrm{r}_{\mathrm{xy}}=-0.426$ denga $\mathrm{p}=0.019(\mathrm{p}<0.05)$, hal ini berarti (Ha) yang berbunyi ada hubungan antara adversity quotient dengan stres kerja pada pegawai bagian protokol pemerintah Provinsi Jambi diterima. Korelasi antara variabel ini memiliki arah yang negatif yang berarti bila salah satu variabel mengalami peningkatan maka akan menurun variabel yang lain, hal ini menandakan semakin tinggi adversity quotient pegawai maka akan semakin rendah stres kerja pegawai tersebut

\section{Pembahasan}

Berdasarkan hasil kategorisasi pada variabel stres kerja, subjek pada penelitian ini berada pada stres kerja dengan kategori tinggi, sedang, dan rendah. Pada kategorisasi tinggi terdapat 4 subjek (13,3\%), kategorisasi sedang terdapat 1 subjek (3,3\%), dan kategorisasi rendah terdapat 25 subjek (83,3\%). Pegawai yang memiliki tingkat stres tinggi berdampak buruk terhadap kerjanya pada bagian protokol. Pada tingkat sedang dapat mengganggu aktivitasnya seharihari. Ini sesuai juga penelitian yang dilakukan Sari, dkk (2014) menyebutkan seseorang yang memiliki tingkat stres berat mengindikasikan kadar stres yang mengganggu kestabilan emosi dan berakibat terganggunya kegiatan sehari-hari. Seseorang yang memiliki tingkat stres ringan mengindikasikan stressor yang ada tidak menyebabkan stres.

Berdasarkan hasil penelitian yang ditinjau dari jenis kelamin, sebagian besar laki-laki berjumlah 16 subjek $(78,6 \%)$ memiliki tingkat stress yang rendah sama seperti jenis kelamin perempuan yang semuanya memiliki tingkat stres kerja yang rendah. Ini dapat diartikan tidak adanya perbedaan jika ditinjau dari jenis kelamin. Hasil penelitian ini juga memiliki kesamaan 
dengan penelitian yang dilakukan oleh Fitri (2013) dimana Jenis Kelamin responden dengan Stres Kerja diperoleh bahwa tidak ada hubungan antara Jenis Kelamin dengan Stres Kerja danhal ini disebabkan oleh banyaknya perempuan yang mengikuti organisasi.

Dari hasil penelitian berdasarkan usia, dapat dlihat usia 42-46 berjumlah 5 subjek $(16,7 \%)$ mempunyai tingkat stres yang rendah. Ini menandakan bahwa usia berpengaruh terhadap tingkat stres kerja, semakin tua maka semakin rendah tingkat stress yang dirasakan. Hasil ini sejalan dengan penelitian Griffiths., dkk (Fitri, 2013) yang mengatakan bahwa Pegawai dengan umur yang lebih tua cenderung mempunyai kondisi kesehatan mental yang lebih baik dibanding pekerja dengan usia yang lebih muda sehingga akan lebih rendah mengalami stress kerja.

Hasil penelitian ini juga diperkuat dengan penelitian yang dilakukan oleh Nitisemito (Haryanti dkk, 2014), bahwa masa kerja adalahsesuatu atau kemampuan yang dimiliki oleh parapegawai dalam menjalankan tugas-tugas yangdibebankan kepadanya. Masa kerja dapatmengontrol terjadinya stres kerja pegawai yang padaawalnya berdampak negatif berubah menjadi positif terhadap kinerja. Didukung pula penelitian yang dilakukan oleh Rumaningsih (Haryanti dkk, 2014) menyatakanbahwa perbedaan individual dari sisi masa kerjamemegang peranan penting dalam menghadapi realitaspekerjaan dan individu yang tetap lebih lama beradadalam pekerjaannya adalah mereka dengan ciri yanglebih tahan terhadap stress kerja, yang akhirnya akan mengembangkan mekanisme untuk mengatasi stress kerja.

Ada banyak faktor yang mempengaruhi tingkat stres individu salah satunya adalah kemampuan AQ yang relatif berbeda pada setiap individu. Menurut Heilrigel dan Slocum (dalam Rosita, 2015) mengatakan bahwa stres kerja dapat disebabkan oleh self efficacy, motivasi dan adversity quotient. Setiap tekanan dari pekerjaan dapat menghasilkan stres kerja. Namun cara individu menyelesaikan tekanan tersebut membuat individu terhindar dari stres kerja. Sari, dkk (2014) mengatakan Individu yang mengenali penyebab (origin) dari stressor yang sedang dihadapinya akan lebih mudah dan efektif dalam menyelesaikan suatu kesulitan karena penyelesaian masalah langsung tertuju pada penyebabnya

Apabila kita melihat hasil asesmen pada bagian protokol pemerintah Provinsi Jambi berdasarkan tingkat adversity quotient yang dimilikinya. Berdasarkan hasil kategorisasi pada 
variabel adversity quotient diatas, subjek pada penelitian ini bserada pada adversity quotient dengan kategori tinggi, sedang dan rendah. Pada kategorisasi tinggi terdapat 26 subjek (86,7\%), kategorisasi sedang terdapat 3 subjek (10\%), dan kategorisasi rendah terdapat 1 subjek (3.3\%). Berdasarkan teori Adversity Quotient (AQ) yang dikembangkan oleh Stoltz (Muhirudin dkk, 2013), AQ seseorang di lihat dari tinggi rendahnya terbagi menjadi tiga tipe.

Ketiga tipe individu tersebut adalah yang pertama Quitters (Orang Menyerah), Merupakan tipe individu yang kurang memiliki kemauan untuk menerima tantangan dalam hidupnya. Berfikir negatif, memiliki konsep diri negatif, selalu merasa tidak mampu. Dorongan dasar manusia sebagai pendaki diabaikan. Masalah adalah jalan buntu bagi dirinya. Mereka menjalani kehidupan yang tidak menyenangkan, dengan setumpuk masalah yang menindihnya. Dari hasil penenlitian ini tergolong dalam tipe Quitters berjumlah 1 subjek (3,3\%).

Kedua Campers (Orang Berkemah), kelompok individu yang sudah memiliki kemauan untuk berusaha dan sudah mencoba menjalankan usaha. Terpaan badai pernah dihadapi, sengatan terik matahari dirasakan, cuaca dingin dan kegelapan ditembus. Tantangan terasa terlalu banyak dan berat. Tidak mampu melangkah lagi. Dengan ringkas dapat dikatakan, bahwa campers adalah orang yang sudah merasa puas dengan zona nyaman yang mereka temui. Dari hasil penelitian ini tergolong dalam tipe Campers berjumlah 3 subjek (10\%).

Ketiga Climbers (Pendaki), merupakan kelompok yang menghadapi berbagai macam hambatan. Mereka yang memiliki semangat hebat, pantang menyerah, tidak pernah mengeluh dalam menghadapi permasalahan. Dia yakin setiap masalah pasti ada jalan keluarnya. Setiap satu kesulitan ada banyak kemudahan. Dari hasil penelitian ini yang tergolong kepada tipe Climbers berjumlah 26 subjek (86,7\%).

Seseorang pegawai yang memiliki AQ yang tinggi tentunya dapat berkontribusi dengan maksimal untuk bagian protokol dalam menjalankan tugas yang diberikan. Setiap individu menjalankan dengan senang hati tanpa ada hambatan apapun. Karena menurut mereka hambatan tersebut menjadi tantangan yang harus dipecahkan agar menjadi lebih baik lagi kedepannya.

Ini sejalan menurut Stoltz (Rosita, 2015) karyawan yang memiliki adversity quotient (AQ) yang tinggi akan memiliki kekebalan atas ketidakmampuan dirinya menghadapi masalah dan 
tidak akan mudah terjebak dalam kondisi keputusasaan. Namun sebaliknya, jika seseorang karyawan memiliki adversity quotient (AQ) yang rendah maka karyawan tersebut akan mudah rapuh dan menyerah pada keadaan.

Dari data tingkat AQ ditinjaudari usia, hampir semua usia berada di tingkat AQ yang tinggi. Ini menandakan tidak ada perbedaan untuk faktor usia dalam tingkat AQ pada pegawai protokol. Hanya ada 1 subjek berada di tingkat rendah. Hal ini sejalan dengan penelitian yang dilakukan oleh Tigcheelar (2015) yang menghasilkan signifikan antara skor keseluruhan AQ dan usia. Karena itu berarti, skor AQ keseluruhan dan usia responden tidak berhubungan secara signifikan. Hasilnya menunjukkan bahwa tanpa memandang usia, para pemimpin bisnis Mesir memiliki kemampuan untuk menangani dan mengatasi situasi sulit yang mungkin mereka hadapi.

Berdasarkan hasil analisa yang dilakukan pada variabel adversity quotient dan stres kerja pegawai bagian protokol pemrintah Provinsi Jambi dapat dijelaskan sebagai berikut. Analisis korelasi menunjukkan bahwa korelasi variabel adversity quotient dengan stres kerja sebesar $\mathrm{r}_{\mathrm{xy}}=$ -0.426 denga $\mathrm{p}=0.019$ ( $\mathrm{p}<0.05)$, hal ini berarti $(\mathrm{Ha})$ yang berbunyi ada hubungan antara adversity quotient dengan stres kerja pada pegawai bagian protokol pemerintah Provinsi Jambi diterima. Korelasi antara variabel ini memiliki arah yang negatif yang berarti bila salah satu variabel mengalami peningkatan maka akan menurun variabel yang lain, hal ini menandakan semakin tinggi adversity quotient pegawai maka akan semakin rendah stres kerja pegawai tersebut.

Penelitian ini sejalan dengan penelitian yang dilakukan oleh Sari (2014) menyebutkan Adversity Quotient berpengaruh terhadap tingkat stres. Pegawai bagian protokol mampu dalam menghadapi masalah yang dihadapinya. Pegawai dapat mengatasi kesulitan menjadi kesempatan dan tantangan untuk dihadapi dengan kemampuan AQ yang dimilikinya. Sehingga pegawai bagian protokol pemerintah Provinsi Jambi jika memiliki AQ yang tinggi maka tingkat stres kerjanya akan rendah. Dan sebaliknya jika memiliki stres kerja yang tinggi maka AQ nya pun menjadi rendah pula.

Hal ini sejalan dengan penelitian yang dilakukan oleh Rosita (2015) terhadap 84 orang karyawan back office PT. Firmindo Ditamandiri Samarinda yang mengatakan semakin tinggi $A Q$ 
seseorang maka semakin rendah tingkat stres kerja orang tersebut. Adversity Quotient secara signifikan mempengaruhi stres kerja. Kemudian, diperkuat lagi dengan penelitian yang dilaksanakan oleh Shen (2014) pada karyawan di sebelas perusahaan di zona industri Taipei, Taoyuan,dan Hsinchu di Taiwan dengan 566 responden. Mengahasilkan validasi adalah signifikan. Hasilnya menunjukkan bahwa ketika skor Adversity Quotient lebih tinggi, stres kerja akan lebih rendah. Oleh karena itu, Adversity Quotient tinggi dapat secara efektif moderat dan lebih rendah Stres kerja. Berdasarkan penjelasan di atas, Pegawai yang mempunyai adversity quotient yang tinggi tentunya mampu dalam mengatasi kesulitan-kesulitan yang ada sehingga pegawai tidak mengalami stres kerja. Hal ini lah yang harus diperhatikan oleh bagian Protokol untuk memberikan pelayanan yang terbaik.

\section{Kesimpulan}

Berdasarkan hasil penelitian yang dilakukan pada pegawai bagian protokol Pemerintah Provinsi Jambi. Jika dilihat berdasarkan hasil kategorisasi pada variabel stres kerja di atas, subjek pada penelitian ini berada pada stres kerja dengan kategori tinggi, sedang, dan rendah. Subjek pada penelitian ini paling banyak berada pada tingkat stres kerja yang rendah, sedangkan kategori sedang paling rendah. Selain itu, hasil kategorisasi pada variabel adversity quotient diatas, subjek pada penelitian ini berada pada adversity quotient dengan kategori tinggi, sedang dan rendah. Paling banyak pada kategori tinggi dan paling sedikit pada kategori rendah. Kemudian, hipotesis (Ha) yang berbunyi ada hubungan antara adversity quotient dengan stres kerja pada pegawai bagian protokol pemerintah Provinsi Jambi diterima. Korelasi antara variabel ini memiliki arah yang negatif yang berarti bila salah satu variabel mengalami peningkatan maka akan menurun variabel yang lain. Hal ini menunjukkan bahwa semakin tinggi adversity quotient pegawai maka akan semakin rendah stres kerja pegawai tersebut. Begitu juga sebaliknya, semakin tinggi stres kerja pegawai maka akan semakin rendah adversity quotient pegawai tersebut.

Saran

Penelitian ini masih terbatas karena hanya meneliti hubungan antar aadversity quotient dengan stress kerja. Dengan demikian masih ada variabel lain yang turut memberikan 
pengaruh pada stress kerja seorang pegawai yang belum dijelaskan dan diteliti, untuk itu diharapkan peneliti selanjutnya dapat menggunakan faktor yang lainnya dan menjadikan penelitian ini sebagai referensinya.

\section{Referensi}

Ardyanti, S. I., \& Harini, E. (2015). Hubungan antara adversity quotient, self efficacy dan kebiasaan belajar dengan prestasi belajar matematika siswa kelas x kecantikan SMK Negeri SeKecamatan Umbulharjo. Jurnal Pendidikan Matematika, 3 (1), 33-43.

Chizanah, L. \& Hadjam, M. N .R. (2011). Validitas konstruk ikhlas: analisis faktor eksploratori terhadap instrumen skala ikhlas. Jurnal Psikologi, 38 (2), 199 - 214.

Fatikhin, F., Hamid, D., Mukzam, M. D. (2017). Pengaruh konflik kerja dan stres kerja terhadap kinerja karyawan. Jurnal Administrasi Bisnis, 47 (1), 172-180.

Felanny., \& Moekardjono, S. R. (2013). Hubungan stres kerja dan kepuasaan kerja pada karyawan Perusahaan X. Jurnal NOETIC Psychology, 3 (2), 196-207.

Fitri, A. M. (2013). Analisis faktor-faktor yang berhubungan dengan kejadian stres kerja pada karyawan bank (Studi pada Karyawan Bank BMT). Jurnal kesehatan masyarakat, 2 (1), 110.

Handaru, A. W., Parimita, W., \& Mufdhalifah, I. W. (2015). Membangun intensi berwirausaha melalui adversity quotient, self efficacy, dan need for achievement. Jurnal Manajemen dan Kewirausahaan, 17 (2), 145-166.

Hanifa, Y. (2017). Hubungan antara emotional quotient dan adversity quotient dengan kecemasan menghadapi dunia kerja pada siswa SMK Muhammadiyah I Samarinda. Psikoborneo, 5 (1), 43-55.

Haryanti., A. F., \& Purwaningsih, P. (2013). Hubungan antara beban kerja dengan stres kerja perawat di Instalasi Gawat Darurat RSUD Kabupaten Semarang. Jurnal Manajemen Keperawatan, 1 (1), 48-56.

Haryanti, N. P. P., \& Ardana, I K. (2014). Analisis pengaruh stres kerja dan motivasi intrinsik terhadap kinerja karyawan dengan pengalaman kerja sebagai variabel pemoderasi. Jurnal Manajemen, Strategi Bisnis dan Kewirausahaan, 8 (2), 156-165.

Hernani. (2014). Studi Tentang penerapan kegiatan keprotokolan di Kantor Gubernur Provinsi Kalimantan Timur. E-Journal Komunikasi, 2 (3), 83-93. 
Marchelia, V. (2014). Stres kerja ditinjau dari shift kerja pada karyawan. Jurna lIlmiah Psikologi Terapan, 2 (1), 130-143.

Muhirudin. (2013). Determinasi adversity quotient, etos kerja, dan kualifikasi akademik terhadap kinerja konselor SMP Negeri di Lombok Timur. e-Journal Program Pascasarjana Universitas Pendidikan Ganesha, 3, 1-8.

Noor, N. N., Rahardjo, K., \& Ruhana, I. (2016). Pengaruh stres kerja dan kepuasan kerja terhadap kinerja karyawan. Jurnal Administrasi Bisnis, 31 (1), 9-15.

Nur, S. (2013). Konflik, stres kerja dan kepuasaan kerja pengaruhnya terhadap kinerja pegawai pada Universitas Khairun Ternate. Jurnal EMBA, 1 (3), 739-749.

Nurhayati., \& Fajrianti, N. (2012). Pengaruh adversity quotient (aq) dan motivasi berprestasi terhadap prestasi belajar matematika. Jurnal Formatif, 3 (1), 72-77.

Oemar, U., \& Gangga, L. (2017). Pengaruh stres kerja terhadap kinerja pegawai pada Dinas Pendapatan, Keuangan dan Aset Daerah Kabupaten Musi Manyuasin. Jurnal Ecoment Global, 2 (2), 22-34.

Peraturan Daerah Provinsi Jambi Nomor 3 Tahun 2015

Periantalo, J. (2015). Penyusunan skala psikologi: asyik, mudah \& bermanfaat. Yogyakarta: PustakaPelajar.

Periantalo, J. (2016). Penelitian kuantitatif untuk psikologi. Yogyakarta: Pustaka Pelajar.

Putra, I. B. K. S. D., \& Rahyuda, A. G. (2015). Pengaruh lingkungan kerja fisik dan stres kerja terhadap kinerja pegawai di UPT. Pengujian Kendaraan Bermotor Dinas Perhubungan Kota Denpasar. E-Jurnal Manajemen Unud, 4 (9), 2491-2506.

Rosita. (2015). Pengaruh adversity quotient dan stres kerja terhadap perilaku prokrastinasi pada karyawan. Jurnal humaniora, 3 (1), 1-21.

Rumimpunu \& Joune, R. C. (2015). Pengaruh kompetensi dan stres kerja terhadap kinerja pegawai pada Dinas Pendidikan Nasional Provinsi Sulut. Jurnal EMBA, 3 (3), 1243-1253.

Sari, C., Firdaus, \& Risma, D. (2014). Hubungan adversity quotient dengan tingkat stres pada mahasiswa tahun pertama Fakultas Kedokteran Universitas Riau. Jurnal UNRI, 1 (2), 920. 
Shen, C. Y. (2014). The Relative study of gender roles, and job stress and adversity quotient. Journal of Global Business Management, 10 (1), 19.

Sukardewi, N., Dantes, N., \& Natajaya, N. (2013). Kontribusi adversity quotient (aq), etos kerja, dan budaya organisasi terhadap kinerja guru SMA negeri di Kota Amlapura. E-Journal Program Pascasarjana Universitas Pendidikan Ganesha, 4, 1-12.

Tigchelaar, L., \& Bekhet, K. E. The relationship of Adversity Quotient and Personal Demographic Profile of Private Business Leaders in Egypt. International Journal of Sciences: Basic and Applied Research (IJSBAR), 20 (1), 403-42.

Undang-Undang Republik Indonesia Nomor 9 Tahun 2010 Tentang Keprotokolan.

Utami, E. W., \& Dewanto, A. (2013). Pengaruh adveristy quotient terhadap kinerja perawat dengan motivasi kerja sebagai variabel mediasi (studi di RSUD "Ngudi Waluyo" Wlingi). Jurnal Aplikasi Manajemen, 11 (1), 1-11.

Vinas, D. K. D., Malabanan, M. G. A. (2015). Adversity quotient and coping strategies of college student in lyceum of the Philippines University. Asia Pacific Journal of Education, Arts and Sciences, 2 (3), 68-72.

Wardiana, I P. A. (2014). Hubungan antara adversity quotient dan minat belajar dengan prestasi belajar matematika pada siswa kelas v sd di Kelurahan Pedungan. Jurnal Mimbar PGSD Universitas Pendidikan Ganesha, 2 (1), 11-21.

Widyowati, A., \& Priambodo, E. P. (2016). Hubungan antara kepekaan humor dengan stres kerja pada pegawai Balai Karantina Pertanian Kelas I Semarang Jawa Tengah. Psikologika, 21 (1), 47-56.

Wisesa, D., \& Indrawati, K. R. (2016). Hubungan adversity quotient dengan motivasi berwirausaha pada mahasiswa Universitas Udayana yang mengikuti program mahasiswa wirausaha. Jurnal Psikologi Udayana, 3 (2), 187-195. 